2013s-36

\title{
Who hires foreign domestic workers? Evidence from Lebanon
}

\author{
Ali Fakih, Walid Marrouch
}

\begin{tabular}{c}
\hline Série Scientifique \\
Scientific Series
\end{tabular}

Montréal

Septembre 2013

(C) 2013 Ali Fakih, Walid Marrouch. Tous droits réservés. All rights reserved. Reproduction partielle permise avec citation du document source, incluant la notice (C).

Short sections may be quoted without explicit permission, if full credit, including (C) notice, is given to the source.
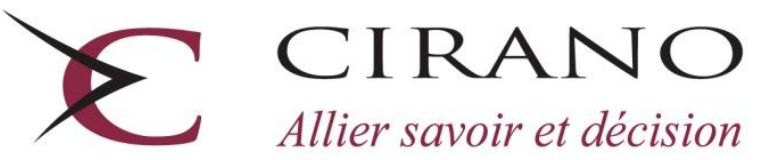

Allier savoir et décision

Centre interuniversitaire de recherche en analyse des organisations 


\section{CIRANO}

Le CIRANO est un organisme sans but lucratif constitué en vertu de la Loi des compagnies du Québec. Le financement de son infrastructure et de ses activités de recherche provient des cotisations de ses organisations-membres, d'une subvention d'infrastructure du Ministère du Développement économique et régional et de la Recherche, de même que des subventions et mandats obtenus par ses équipes de recherche.

CIRANO is a private non-profit organization incorporated under the Québec Companies Act. Its infrastructure and research activities are funded through fees paid by member organizations, an infrastructure grant from the Ministère du Développement économique et régional et de la Recherche, and grants and research mandates obtained by its research teams.

\section{Les partenaires du CIRANO}

\section{Partenaire majeur}

Ministère de l'Enseignement supérieur, de la Recherche, de la Science et de la Technologie

Partenaires corporatifs

Autorité des marchés financiers

Banque de développement du Canada

Banque du Canada

Banque Laurentienne du Canada

Banque Nationale du Canada

Banque Scotia

Bell Canada

BMO Groupe financier

Caisse de dépôt et placement du Québec

Fédération des caisses Desjardins du Québec

Financière Sun Life, Québec

Gaz Métro

Hydro-Québec

Industrie Canada

Investissements PSP

Ministère des Finances et de l'Économie

Power Corporation du Canada

Rio Tinto Alcan

State Street Global Advisors

Transat A.T.

Ville de Montréal

\section{Partenaires universitaires}

École Polytechnique de Montréal

École de technologie supérieure (ÉTS)

HEC Montréal

Institut national de la recherche scientifique (INRS)

McGill University

Université Concordia

Université de Montréal

Université de Sherbrooke

Université du Québec

Université du Québec à Montréal

Université Laval

Le CIRANO collabore avec de nombreux centres et chaires de recherche universitaires dont on peut consulter la liste sur son site web.

Les cahiers de la série scientifique (CS) visent à rendre accessibles des résultats de recherche effectuée au CIRANO afin de susciter échanges et commentaires. Ces cahiers sont écrits dans le style des publications scientifiques. Les idées et les opinions émises sont sous l'unique responsabilité des auteurs et ne représentent pas nécessairement les positions du CIRANO ou de ses partenaires.

This paper presents research carried out at CIRANO and aims at encouraging discussion and comment. The observations and viewpoints expressed are the sole responsibility of the authors. They do not necessarily represent positions of CIRANO or its partners. 


\title{
Who hires foreign domestic workers? Evidence from Lebanon
}

\author{
Ali Fakih ${ }^{*}$, Walid Marrouch ${ }^{\dagger}$
}

\begin{abstract}
Résumé/abstract
Foreign domestic workers' activities provide important market and non-market services in a large number of middle-income countries as these activities have an impact on the labor force participation and time allocation decisions of household members. This paper provides new evidence on the determinants of foreign domestic workers' employment using a socio-economic dataset from Lebanon. Controlling for household, household head, dwelling and regional characteristics, contrary to popular beliefs we find that the size of the household and the presence of elderly persons are not important determinants of the hiring decision of foreign domestic workers, while the probability of hiring a domestic worker is significantly higher for households with children and disabled persons. Interestingly, we find that the number of rooms in the residence rather than its total surface area or type to be the only relevant dwelling characteristic. The paper offers insights about the demand for foreign domestic workers that may be useful to policy makers in developing nations.
\end{abstract}

Mots clés/keywords : Foreign domestic workers; Demand for domestic work;

Household level data

Codes JEL : D13; J23; J49

\footnotetext{
* CIRANO and Department of Economics, Lebanese American University, P.O. Box: 13-5053, Chouran Beirut 1102 2801, Lebanon, Center for Interuniversity Research and Analysis on Organizations (CIRANO), Montreal, Canada, Institute for the Study of Labor (IZA), Bonn, Germany.

${ }^{\dagger}$ Corresponding author. Phone number: +961-1786456. E-mail address: walid.marrouch@lau.edu.lb, CIRANO and Department of Economics, Lebanese American University, P.O. Box: 13-5053, Chouran Beirut 1102 2801, Lebanon, Center for Interuniversity Research and Analysis on Organizations (CIRANO), Montreal, Canada.
} 


\section{Introduction}

Foreign domestic workers' (FDWs) employment provide important market and non-market services in a large number of middle-income countries as these activities have an impact on the labor force participation and time allocation decisions of household members. ${ }^{1}$ In developed countries, the labor market of FDWs is accessible only to the wealthy where the costs of recruiting workers are substantial and this market is characterized by relatively high pay (for example, see the Hong Kong case in Suen, 1993). However, in most developing nations including middle-income countries, the demand for FDWs not only originates from the wealthy but also from the middle class. Moreover, a part of the services provided by foreign domestic workers substitute for institutional care set by governments especially in developing countries who lack the proper infrastructure for such institutions. ${ }^{2}$ Also, the availability of FDWs may have an impact on the individual family planning and the female labor participation decisions in the host country. It is therefore interesting to examine the socio-economic profile of the demand side of the FDWs market in a middle-income country by investigating the case of Lebanon. This is because our study presents quantifiable evidence that may help policymakers in their regulation of the domestic workers market.

Factors that determine the hiring decision of foreign domestic workers has received little attention in the economics literature. A few studies have examined the decision to hire domestic workers within the labor supply literature using the hiring decision as an explanatory variable for the time allocation decision of the household. Pollak and Wachter (1975), in a paper about the use of domestic workers in general, argue that when women attach utility to time spent on home activities; the demand for domestic workers will be an imperfect substitute for self-produced domestic work. By the same token, Kimmel and Connelly (2007) examine the determinants of mothers' time for paid and unpaid work using US data in 2003 and 2004. They find that time allocated to home production activities is decreasing in the wage of employed mothers. Khan (2012) provides new insights on the time allocation decision of households in rural South Asia. She finds that increasing subsidies to poor households will increase the supply of young female domestic workers instead of female schooling rates. When it comes to foreign domestic workers, Suen (1993) uses data from Hong Kong and finds by examining the supply side that women who hire a FDW are more likely to participate in the labor market. Recently, Cortés and Pan (2013) analyze the impact of hiring FDWs on the female labor force participation in Hong Kong and 
Taiwan. They find that the presence of FDWs in the household increases the participation of mothers with a young child compared to older children by 10 to $14 \%$. Their results indicate that FDWs can be used as a market based alternative to childcare subsidies.

A number of conceptual issues arise when paid domestic work is used as a substitute for care giving. Blackett (2011) notes that in industrialized countries, post-World War II demographic changes and the establishment of welfare states increased the supply of institutional care lowering the demand for domestic workers. In contrast, the welfare state apparatus is less developed in developing countries including those in the Middle-East. According to Ireland (2011), care work in the Middle-East is mostly informal and taken up by female members in the extended family. Thus, care giving provided by FDWs is supplementary to the role of the extended family and can be seen as a substitute to institutional care. Shah et al. (2012) lend support to this observation. They use data on households with elderly persons above 70 years of age in Kuwait and find that $28 \%$ and $58 \%$ of elderly men and women with activities of daily living, respectively, hired a FDW.

Empirical studies on the labor demand side looking into the determinants of domestic workers' employment are also scant. Flipo et al. (2007) present evidence from French households using data on tax deductions. They find that the likelihood of households demanding domestic services is positively correlated with their age and income. Using Australian data, Baxter et al. (2009) find that income predicts the use of paid domestic help. They also find that men with spouses in poor health conditions are more likely to employ domestic workers. Stancanelli and Stratton (2010) analyze French and British data and find that couples using maids' services as an alternative to their domestic work effort are more likely to do so on weekends. They also find that women's wages have the highest explanatory power for the time allocated to domestic work and indirectly for the demand for maid services. Finally, to the best of our knowledge the only paper that examines the demand for foreign domestic workers is by Suen (1993) who also examined the supply side as was discussed above. The author notes that contracted domestic work is a normal good. He finds that the probability of hiring a domestic worker is increasing in non-wage income.

This paper contributes to the latter strand of literature by providing new evidence on the determinants of employing foreign domestic workers. Specifically, we examine the demand for FDWs by comparing the relevance of three categories of variables, i.e. household, household 
head and dwelling characteristics. This study answers two research questions: i) what are the determinants of hiring FDWs in Lebanon? ii) Is there evidence that the use of FDWs resembles institutional care for dependents? To the best of our knowledge, this paper is the first to provide empirical evidence related to these questions from a developing country. We use data from the National Household Budget Survey (2005). This survey has two important distinct features. First, it is the only Lebanese dataset containing information about FDWs use at the national level, and is representative of all Lebanese households. Second, it allows us to control for regional effects. Following Suen (1993), Flipo et al. (2007) and Stancanelli and Stratton (2010), we measure the impact of relevant variables on the likelihood of hiring foreign domestic helpers by estimating a probit model.

The remainder of the paper is organized as follows. Section 2 presents an overview on domestic workers in the Middle East and Lebanon. Section 3 describes the data used and the empirical methodology. The empirical findings are discussed in section 4. Finally, section 5 makes concluding remarks.

\section{Domestic workers in the Middle East and Lebanon}

The past two decades witnessed a noted increase in the flow of migrant female workers with low-skills from South Asia, South East Asia, and East Africa to the Middle East. Official estimates put the number of domestic workers at 53 million around the world (ILO, 2013). However, the ILO reckons that this number could be seriously underestimated given the often informal nature of domestic work activities. Moreover, most domestic workers are female and foreign (migrants) according to the ILO. Table 1 presents some comparative statistics on the female domestic labor market -including both local and foreign workers- by economic region around the world. The table shows that the proportion of female domestic workers to total female employment is the highest in the Middle East region. Also, looking at the Latin America and Caribbean region highlights the large contribution of the domestic workers market to total female employment in middle-income countries. Esim and Kerbage (2011) indicate that in the Middle East region there were around 1.7 million foreign domestic workers of both sexes in 2009 . 
Table 1: Female domestic workers by economic region in 2010

\begin{tabular}{lcc}
\hline & $\begin{array}{c}\text { Female domestic } \\
\text { Workers }\end{array}$ & $\begin{array}{c}\text { Female domestic workers } \\
\text { as percentage of } \\
\text { female employment }\end{array}$ \\
\hline Middle East & $1,329,000$ & 20.5 \\
\hline Developed countries & $2,597,000$ & 1.3 \\
Eastern Europe and CIS & 396,000 & 0.4 \\
Asia and the Pacific & $17,464,000$ & 2.5 \\
Latin America and Caribbean & $18,005,000$ & 17.4 \\
Africa & $3,835,000$ & 2.5 \\
\hline Total & $43,628,000$ & 3.5 \\
\hline
\end{tabular}

Source: International Labour Organization (2013).

In Lebanon, there is a growing public interest in the FDWs industry related to adverse employment conditions and human rights abuses. For example, in 2012, a typical FDW received on average a wage equal to $\$ 250 /$ month, which is below the official minimum wage. ${ }^{3}$ One possible explanation behind the relatively low wages is the existence of a large degree of competition between work agencies who hire foreign domestic workers from various geographic regions in Asia and Africa. This reality downwards pressure on wages. ${ }^{4}$ An additional explanation is the absence of a proper regulation of the industry. According to the Lebanese Ministry of Labor, Lebanon hosted 117,941 paid foreign domestic workers in 2010 of which 97\% were women (see Table 2). ${ }^{5}$ In the aftermath of the civil war (1975-1990), Lebanon witnessed a surge in the arrival of FDWs from South Asia, South East Asia, and East Africa. Table 2 shows the breakdown of these FDWs by nationality. The largest group of registered domestic workers originates from Ethiopia constituting around $27 \%$ of all FDWs working in Lebanon in 2010. Moreover, most domestic workers live with their employer for the duration of their contract. Domestic work and its direct activities led to the establishment of a dedicated industry in Lebanon. In 2010, the estimated total direct cost of recruiting new FDWs was around US $\$ 290$ million, while the total wage bill for all domestic workers was around US $\$ 300$ million. ${ }^{6}$ 
Table 2: Foreign domestic workers in Lebanon by nationality in 2010

\begin{tabular}{lcc}
\hline Nationality & Number & Percentage \\
\hline Ethiopia & 31,556 & 26.80 \\
Philippines & 29,049 & 24.60 \\
Bangladesh & 24,081 & 20.40 \\
Sri Lanka & 12,527 & 10.60 \\
Nepal & 11,975 & 10.20 \\
Madagascar & 3,470 & 2.90 \\
Other Nationalities & 5,283 & 4.50 \\
\hline Total & 117,941 & 100 \\
\hline
\end{tabular}

Source: Lebanese Ministry of Labor, tabled by Hamill (2011).

\section{Data and methodology}

\subsection{Data}

We use a socio-economic dataset on Lebanese households drawn from the National Household Budget Survey (2005) conducted by Central Administration of Statistics (CAS), the Ministry of Social Affairs and the United Nations Development Programme (UNDP). The sample design is nationally representative for all Lebanese households and is weighted to take into account the regional distribution of the population. The dataset includes information on households' characteristics and their living conditions. The relevant survey data used in this paper covers 7431 households with respondents aged at least 15 years spanning all six Lebanese administrative regions (Mohafazas). It should be noted that this survey excludes non-Lebanese residents.

Table 3 presents the proportion of households employing FDWs by characteristic in 2005. We observe that $5.60 \%$ of households with elderly persons employ FDWs. However, only $2.95 \%$ of households with children aged between 0 and 6 years have FDWs. It is interesting to note that $14.34 \%$ of university educated household heads employ foreign domestic helpers. Regarding the dwelling characteristics, we notice that around $29 \%$ of villa owners used the services of foreign domestic helpers. Finally, the poorest regions (the North and the Bekaa Mohafazas) have the lowest percentage of households employing foreign domestic workers, as opposed to Beirut the capital and most developed region in the country where the percentage is around $12 \%$. 
Table 3: Percentage of households employing domestic worker(s) by characteristic in 2005

\begin{tabular}{lc}
\hline \hline Variable & Percentage \\
\hline \hline All characteristics & \\
$\quad$ Overall average of households employing FDWs & 3.50 \\
Household characteristics & \\
Households with children aged 0 to 6 & 2.95 \\
Households with elderly person(s) & 5.60 \\
$\quad$ Households with disabled person(s) & 5.29 \\
Household head characteristics & \\
Female headed household & 4.96 \\
Head is married & 3.43 \\
Head with university education & 14.34 \\
Dwelling characteristics & \\
If the dwelling is a house & 1.94 \\
If the dwelling is a villa & 29.13 \\
If the dwelling is an apartment & 3.97 \\
Regions (Mohafazas) & \\
Beirut & 11.62 \\
Mount Lebanon & 3.53 \\
North & 1.22 \\
Bekaa & 1.21 \\
South & 2.90 \\
Nabatieh & 2.08 \\
\hline Number of observations & 7,431 \\
\hline \hline
\end{tabular}

Table 4 presents the summary statistics of the variables used in the analysis. The dichotomic dependent variable indicates that $3.5 \%$ of Lebanese households employ FDWs. While, Flipo et al. (2007) report, using a representative sample from France, that $5.9 \%$ of households hired a domestic worker in 1996. The average Lebanese household has 4.3 members. Around $33 \%$ of all households have children aged between 0 and 6 years, 30.6\% have at least one elderly person and $7.6 \%$ have at least one disabled person. The average yearly aggregate household consumption in 2005 is equal to 17.9 million Lebanese pounds - LBP - (US \$11,863). Regarding the household head characteristics, we find that only $13.8 \%$ of families are headed by females. The average age of all household heads is around 50 years, while $80.1 \%$ of household heads are married. We also observe that only $10.2 \%$ of heads have a university education. Finally, we notice that on average the Lebanese dwelling has 3.8 rooms - excluding the kitchen and the washroom(s) - with an average surface area of 127 square meters. Respectively, $74 \%$ of residences are apartments, $25.5 \%$ are houses and only $0.5 \%$ are villas. 
Table 4: Descriptive statistics

\begin{tabular}{|c|c|c|}
\hline Variable & Mean & $\begin{array}{l}\text { Standard } \\
\text { Deviation } \\
\end{array}$ \\
\hline \multicolumn{3}{|l|}{ Dependent variable } \\
\hline Households employ one or more domestic workers ${ }^{\dagger}$ & 0.035 & 0.185 \\
\hline \multicolumn{3}{|l|}{ Household characteristics } \\
\hline Number of household members & 4.323 & 2.031 \\
\hline Households with children aged 0 to $6^{\dagger}$ & 0.334 & 0.471 \\
\hline 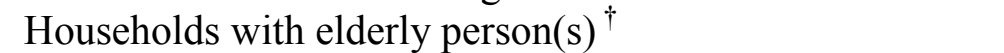 & 0.306 & 0.461 \\
\hline Households with disabled person(s) ${ }^{\dagger}$ & 0.076 & 0.265 \\
\hline Share of unemployed person $(\mathrm{s})^{\dagger}$ & 0.035 & 0.114 \\
\hline Household aggregate yearly consumption (Millions LBP) & 17.876 & 14.130 \\
\hline Household has a marble paved dwelling ${ }^{\dagger}$ & 0.073 & 0.261 \\
\hline Household owns a second dwelling ${ }^{\dagger}$ & 0.083 & 0.275 \\
\hline Household has a dishwasher ${ }^{\dagger}$ & 0.024 & 0.155 \\
\hline \multicolumn{3}{|l|}{ Household head characteristics } \\
\hline Female headed household ${ }^{\dagger}$ & 0.138 & 0.345 \\
\hline Age of the head & 50.061 & 14.894 \\
\hline Head is Married ${ }^{\dagger}$ & 0.801 & 0.399 \\
\hline Head education: primary and below ${ }^{\dagger}$ & 0.550 & 0.497 \\
\hline Head education: intermediate/secondary ${ }^{\dagger}$ & 0.297 & 0.457 \\
\hline Head education: vocational ${ }^{\dagger}$ & 0.044 & 0.206 \\
\hline Head education: university ${ }^{\dagger}$ & 0.102 & 0.303 \\
\hline \multicolumn{3}{|l|}{ Dwelling characteristics } \\
\hline Number of rooms & 3.799 & 1.353 \\
\hline Surface of the roofed residential area & 126.577 & 58.363 \\
\hline If the dwelling is a house ${ }^{\dagger}$ & 0.256 & 0.436 \\
\hline If the dwelling is a villa ${ }^{\dagger}$ & 0.005 & 0.076 \\
\hline If the dwelling is an apartment ${ }^{\dagger}$ & 0.737 & 0.440 \\
\hline \multicolumn{3}{|l|}{ Regional dummies } \\
\hline Beirut $^{\dagger}$ & 0.110 & 0.313 \\
\hline Mount Lebanon ${ }^{\dagger}$ & 0.414 & 0.492 \\
\hline North $^{\dagger}$ & 0.166 & 0.372 \\
\hline Bekaa $^{\dagger}$ & 0.123 & 0.329 \\
\hline South $^{\dagger}$ & 0.116 & 0.320 \\
\hline Nabatieh $^{\dagger}$ & 0.067 & 0.250 \\
\hline \multicolumn{3}{|l|}{ Macro variable } \\
\hline Average regional individual income (Millions LBP) & 8.200 & 0.128 \\
\hline Number of observations & \multicolumn{2}{|c|}{7,431} \\
\hline
\end{tabular}

Notes: ${ }^{\dagger}$ denotes a binary variable.

\subsection{Empirical methodology}

Our goal is to examine the factors that determine the use of FDWs' services. We model the probability of having FDWs using a probit specification. Let $D_{i r}^{*}$ denote the net benefit accruing 
to the household $i(i=1, \ldots, N)$ located in region $r(r=1, \ldots, R)$ from purchasing the service of domestic work, i.e. it is the utility derived from having FDWs in the household. The specification for the probit model can be represented as:

$$
D_{i r}^{*}=X_{i r} \beta+Z_{r} \delta+u_{i r},
$$

where $X_{i r}$ is a vector of variables containing the observable characteristics for households, household heads, and dwellings; $Z_{r}$ represents a vector of regional characteristics where household $i$ is located; $\beta$ and $\delta$ are vectors of parameters to be estimated; and $u_{i r}$ is the error term following a normal distribution. The variable $D_{i r}^{*}$ is not observable as it is a latent variable. Instead, we observe the household's hiring decision. Hence, we define the following probit rule:

$$
D_{i r}=\left\{\begin{array}{llc}
1 & \text { if } & D_{i r}^{*} \geq 0 \\
0 & \text { if } & D_{i r}^{*}<0
\end{array},\right.
$$

where $D_{i r}$ is a binary variable equal to one if the household $i$ in region $r$ states that they have at least one foreign domestic worker ${ }^{7}$ in their employment, and zero otherwise.

\section{Empirical findings}

We estimate the probability of having FDWs using the probit specification in equations (1) and (2). In our regressions, we control for three categories of independent variables. We first examine the significance of household characteristics by including the number of household members, and a list of dummies for children aged 0 to 6 , elderly persons and disabled persons, and the share of unemployed persons in the household. In addition, we consider the aggregate household consumption and a proxy for wealth. The variable wealth considers the ownership of a dishwasher, or a marble paved dwelling, or a second dwelling. Second, we examine the role of household head characteristics by controlling for gender, age, marital status and level of education. Third, we control for the dwelling characteristics including number of rooms, surface of the roofed residential area and dwelling type. We, then consider the full model which includes all the characteristics. We also control for regional effects in all specifications (1) to (5), and we cluster the error term by region. Clustering allows the error terms to be correlated within regions but not between regions and thus provide more accurate standard errors. For robustness check, we add a macro variable to capture regional differences in income and we re-estimate our full 
model in column (6). Finally, examining the different specifications mentioned above allows us to compare between characteristics based on their explanatory power.

Table 5: Determinants of domestic workers' employment decision (probit model, marginal effects)

\begin{tabular}{|c|c|c|c|c|c|c|}
\hline & \multicolumn{6}{|c|}{ Dependent Variable: Household has domestic worker $(s)$} \\
\hline & (1) & (2) & (3) & (4) & (5) & (6) \\
\hline \multicolumn{7}{|l|}{ Household characteristics } \\
\hline Number of household members & $\begin{array}{l}-0.001 \\
(0.001)\end{array}$ & & & $\begin{array}{l}0.001 \\
(0.001)\end{array}$ & $\begin{array}{l}0.001 \\
(0.000)\end{array}$ & $\begin{array}{l}0.001 \\
(0.000)^{*}\end{array}$ \\
\hline Households with children aged $0-6$ & $\begin{array}{l}0.005 \\
(0.001)^{* * *}\end{array}$ & & & $\begin{array}{l}0.008 \\
(0.002)^{* * *}\end{array}$ & $\begin{array}{l}0.007 \\
(0.002)^{* * *}\end{array}$ & $\begin{array}{l}0.008 \\
(0.003)^{* * *}\end{array}$ \\
\hline Households with elderly person(s) & $\begin{array}{l}0.023 \\
(0.006)^{* * *}\end{array}$ & & & $\begin{array}{l}0.005 \\
(0.007)\end{array}$ & $\begin{array}{l}0.004 \\
(0.006)\end{array}$ & $\begin{array}{l}0.004 \\
(0.003)\end{array}$ \\
\hline Households with disabled person(s) & $\begin{array}{l}0.019 \\
(0.013)\end{array}$ & & & $\begin{array}{l}0.014 \\
(0.008)^{*}\end{array}$ & $\begin{array}{l}0.013 \\
(0.007)^{*}\end{array}$ & $\begin{array}{l}0.014 \\
(0.006)^{* *}\end{array}$ \\
\hline Share of unemployed person(s) & $\begin{array}{l}-0.039 \\
(0.022)^{*}\end{array}$ & & & $\begin{array}{l}-0.017 \\
(0.018)\end{array}$ & $\begin{array}{l}-0.018 \\
(0.015)\end{array}$ & $\begin{array}{l}-0.018 \\
(0.011)\end{array}$ \\
\hline Household aggregate consumption & $\begin{array}{l}0.011 \\
(0.001)^{* * *}\end{array}$ & & & $\begin{array}{l}0.005 \\
(0.001)^{* * *}\end{array}$ & $\begin{array}{l}0.004 \\
(0.000) * * *\end{array}$ & $\begin{array}{l}0.005 \\
(0.001)^{* * *}\end{array}$ \\
\hline Wealth & $\begin{array}{l}0.015 \\
(0.004)^{* * *}\end{array}$ & & & $\begin{array}{l}0.007 \\
(0.003) * * *\end{array}$ & $\begin{array}{l}0.005 \\
(0.002)^{* *}\end{array}$ & $\begin{array}{l}0.006 \\
(0.003)^{* *}\end{array}$ \\
\hline Average regional individual income & & & & & & $\begin{array}{l}0.026 \\
(0.008)^{* * *}\end{array}$ \\
\hline \multicolumn{7}{|l|}{ Household head characteristics } \\
\hline Female headed household & & $\begin{array}{l}0.020 \\
(0.005)^{* * *}\end{array}$ & & $\begin{array}{l}0.010 \\
(0.003)^{* * *}\end{array}$ & $\begin{array}{l}0.008 \\
(0.004)^{* *}\end{array}$ & $\begin{array}{l}0.009 \\
(0.007)\end{array}$ \\
\hline Age of the head & & $\begin{array}{l}0.001 \\
(0.000)^{* * *}\end{array}$ & & $\begin{array}{l}0.001 \\
(0.000)^{* *}\end{array}$ & $\begin{array}{l}0.000 \\
(0.000)^{* * *}\end{array}$ & $\begin{array}{l}0.000 \\
(0.000)^{* * *}\end{array}$ \\
\hline Head is Married & & $\begin{array}{l}0.009 \\
(0.002)^{* * *}\end{array}$ & & $\begin{array}{l}-0.006 \\
(0.004)\end{array}$ & $\begin{array}{l}-0.004 \\
(0.003)\end{array}$ & $\begin{array}{l}-0.005 \\
(0.005)\end{array}$ \\
\hline $\begin{array}{l}\text { Head education: } \\
\text { intermediate/secondary }\end{array}$ & & $\begin{array}{l}0.027 \\
(0.006) * * *\end{array}$ & & $\begin{array}{l}0.009 \\
(0.005)^{*}\end{array}$ & $\begin{array}{l}0.006 \\
(0.003)^{*}\end{array}$ & $\begin{array}{l}0.006 \\
(0.003)^{* *}\end{array}$ \\
\hline Head education: vocational & & $\begin{array}{l}0.078 \\
(0.028)^{* * *}\end{array}$ & & $\begin{array}{l}0.032 \\
(0.019)^{*}\end{array}$ & $\begin{array}{l}0.023 \\
(0.013)^{*}\end{array}$ & $\begin{array}{l}0.026 \\
(0.012)^{* *}\end{array}$ \\
\hline Head education: university & & $\begin{array}{l}0.158 \\
(0.012)^{* * *}\end{array}$ & & $\begin{array}{l}0.040 \\
(0.010)^{* * *}\end{array}$ & $\begin{array}{l}0.030 \\
(0.005) * * *\end{array}$ & $\begin{array}{l}0.033 \\
(0.009) * * *\end{array}$ \\
\hline \multicolumn{7}{|l|}{ Dwelling characteristics } \\
\hline Number of rooms & & & $\begin{array}{l}0.012 \\
(0.001)^{* * *}\end{array}$ & $\begin{array}{l}0.005 \\
(0.002)^{* * *}\end{array}$ & $\begin{array}{l}0.004 \\
(0.001)^{* * *}\end{array}$ & $\begin{array}{l}0.004 \\
(0.001)^{* * *}\end{array}$ \\
\hline Surface of the roofed residential area & & & $\begin{array}{l}0.000 \\
(0.000)^{* * *}\end{array}$ & $\begin{array}{l}0.000 \\
(0.000)\end{array}$ & $\begin{array}{l}0.000 \\
(0.000)\end{array}$ & $\begin{array}{l}0.000 \\
(0.000)\end{array}$ \\
\hline
\end{tabular}


If the dwelling is a house

$$
\begin{array}{llll}
-0.006 & -0.004 & -0.002 & -0.002 \\
(0.003)^{* *} & (0.001)^{* * *} & (0.001) & (0.002) \\
-0.006 & -0.003 & -0.002 & -0.002 \\
(0.005) & (0.005) & (0.004) & (0.005)
\end{array}
$$

If the dwelling is a villa

\section{Regional dummies}

Mount Lebanon

$$
\begin{array}{lll}
-0.010 & -0.015 & -0.023 \\
(0.002)^{* * *} & (0.001)^{* * *} & (0.002)^{* * *}
\end{array}
$$$$
-0.005
$$$$
(0.001)^{* * *}
$$

North

$$
-0.015 \quad-0.019 \quad-0.024
$$

$(0.002)^{* * *}(0.001)^{* * *}(0.002)^{* * *}$

$(0.001)^{* * *}$

Bekaa

$$
-0.016
$$

$-0.019$

$-0.020$

$-0.009$

$$
(0.002)^{* * *}(0.001)^{* * *}(0.002)^{* * *}
$$

South

$$
-0.007
$$

$-0.014$

$-0.003$

$$
(0.002)^{* * *}
$$

$(0.001)^{* * *}$

$(0.001)^{* * *}$

$(0.001)^{* *}$

Nabatieh

$$
\begin{array}{lll}
-0.012 & -0.013 & -0.015 \\
(0.002)^{* * *} & (0.001)^{* * *} & (0.001)^{* * *}
\end{array}
$$

$(0.001)^{* * *}$

\begin{tabular}{lllllll}
\hline Ln-Likelihood (pseudo) & -810.967 & -916.371 & -863.406 & -745.814 & -728.166 & -738.233 \\
Number of observations & 7330 & 7330 & 7330 & 7330 & 7330 & 7330 \\
\hline
\end{tabular}

Notes: Statistical significance: $*=10 \% ; * *=5 \% ; * * *=1 \%$. Robust standard errors are in parentheses. They are clustered by region in columns (1) through (5). The reference category for education is primary and below. The reference group for dwelling type is apartment. The reference group for regional dummies is Beirut.

\subsection{Household characteristics}

The estimation results are presented in Table 5. The results reveal that the household characteristics are important determinants of the FDWs' hiring decision. Having children aged between 0 and 6 and disabled persons living in the household increases the probability of hiring FDWs in column 1. These results are robust to different model specifications. The presence of these dependents increases the demand for domestic workers because, in Lebanon, a large part of FDWs' work is a close substitute for baby-sitting and care-giving work. FDWs are in fact contractually expected to provide these services when the need arises in addition to help with everyday domestic chores (see for example the Spanish case in Farré et al., 2011, or the case of Hong Kong and Taiwan in Cortés and Pan, 2013). Baxter et al. (2009) find that in Australia this probability is increasing in the number of children for female headed household but decreasing for male headed household, while Flipo et al. (2007) find that the probability is decreasing for households with children due to the separation of child care and domestic chores services in France. All these results indicate that the effects are sensitive to differences in social norms and institutions. Our results also indicate that having an elderly person in the household is positively 
significant in column 1. However, when the full model is considered, this variable is no longer statistically significant in columns 4 and 5 , underlining the importance of correctly specifying the set of regressors. Our result is in line with well-established evidence in the sociology literature that indicates that downward solidarity (from parents to children) is stronger than upward solidarity (from children to parents) (see Bengtson and Kuypers, 1971; Hammarström, 2005). This suggests that child care will receive more attention than geriatric care in a given household, raising significantly the demand for domestic workers in the former case but not in the latter. We find that the household aggregate consumption increases the probability of having a foreign domestic worker across all model specifications. Being a flow variable, household aggregate consumption is a good proxy for household disposable income. Thus, our result suggests that domestic work services are a normal good. Additionally, the estimates for our variable wealth indicate that wealthy families are more likely to hire a FDW. As a matter of fact, ownership of a dwelling paved with marble, or a second dwelling or a dishwasher are all strong indicators of wealth in Lebanon. ${ }^{8}$

\subsection{Household head characteristics}

We find that female headed households are more likely to employ FDWs. Females who head households are typically participating in the labor market, and therefore their demand for domestic labor compensate for the reduction in the time spent on domestic chores. This explanation is consistent with results found in some previous studies (e.g. Suen, 1993; Chan, 2006; Flipo et al., 2007; Cortés and Pan, 2013). This result is maintained in the full model. It should be noted that although female labor participation and the maid hiring decision are simultaneous variables (Suen, 1993), the dummy female headed households is an exogenous variable in the model as it is not affected by the maid hiring decision. ${ }^{9}$ We also find that the likelihood of hiring FDWs is increasing with the age of the head. This finding suggests that cohort effects may play a role in the demand for FDWs. This result lends support to Flipo et al.'s (2007) finding that the probability of hiring is influenced by age of the head in France. Baxter $e t$ al. (2009) also confirm that age is positively correlated with the hiring decision.

With regard to the level of education, we find that the higher the level of education is, the higher the probability of hiring a FDW. The categories "Intermediate/Secondary", "Vocational" and "University" are all positively correlated with the probability of having a domestic worker where the reference group is "Primary and no Education". This finding suggests that a higher level of 
education, thus a higher socio-economic status would lead to a higher demand for domestic workers. This result lends support to Baxter et al. (2009) who also find that having an undergraduate university degree is positively correlated with having a domestic worker. Suen (1993) finds a similar effect in Hong Kong.

\subsection{Dwelling characteristics}

Turning to the dwelling characteristics, we find that the number of rooms excluding the kitchen and the bathroom(s) is an important determinant. The probability of the hiring decision is increasing in the number of rooms. ${ }^{10}$ This result is maintained across different specifications. Surprisingly, the surface of the living area is found to be insignificant suggesting that the dwelling configuration rather than its surface area positively correlates with the hiring decision. In other words, for the same surface area a dwelling with more rooms is more likely to host a foreign domestic worker especially that this worker will be living typically in a separate room. Finally, when the dwelling is a house it is less likely to have a foreign domestic worker where the reference group is defined to be an apartment type dwelling. This a priori surprising result can be explained by the fact that houses are usually found outside the capital city Beirut. Families who live in houses are in a more traditional rural setting where hiring FDWs is not a prevalent social norm. However, when we consider the full model in column 5 the type of dwelling is no longer a significant determinant.

\subsection{Regional effects}

We find that all regional dummies exhibit a negative sign where the reference group is the capital city Beirut. The probability of having a foreign domestic worker is decreasing in all regions (five Mohafazas) outside the capital city. It is interesting to notice that the two most rural and poorest Mohafazas in Lebanon (the North and the Bekaa) are associated with the strongest negative and significant regional effect on the likelihood of employing FDWs. For robustness check, we run in column 6 the full model excluding the regional dummies and we consider instead a macro variable that measures the average regional individual income in the year 2005, which is the same year when the household survey was conducted. Overall, the results remain qualitatively unchanged to those presented in column 5 except for the variables household size and female headed household since regional income effects absorb some inter-household variations through our dataset. The estimate for the average regional individual income is positive and statistically 
significant at the $1 \%$ level. This means that an increase in the regional individual income increases the probability of hiring a FDW. The positive sign of this variable underscores that the regions with higher individual income are more likely to hire FDWs.

\section{Concluding remarks}

Our results can be potentially useful for policymakers in their effort to regulate the industry revolving around domestic work. Comparing the likelihood levels from different empirical specifications, we notice that household characteristics have the largest explanatory power when compared to either household head or dwelling characteristics. Specifically, we find that households with dependents (children and disabled persons) are more likely employers of FDWs indicating that domestic work is used as a substitute for the provision of institutional care. This highlights a need for greater public investment in the care economy so that families can have the option to choose between institutional care and private provision of the necessary care services through FDWs who should be selected based on their care giving qualification.

Furthermore the trade-off between institutional care and private care provided by foreign domestic workers could be more severe in rural areas. The negative relationship between the FDWs' hiring decision and the relative poverty of rural areas implies that the government has an important role in regulating the foreign domestic work industry. One regulation could be to reduce explicit and implicit costs of hiring FDWs in rural areas. These costs are explicit because every FDW should have a sponsor and should renew her residency every year at a cost that is prohibitive to some households. They are implicit because current practices prevent potential employers from hiring directly a FDW as they must use the service of an intermediary. As the government reduces both the explicit and implicit costs and more FDWs hired in rural areas, this could be a remedy to substitute for the poor access to institutional care in such remote areas, which lack adequate health care infrastructure such as hospitals and geriatric or pediatric care centers.

Our finding that the likelihood of hiring a domestic worker is increasing in the level of education suggests that household heads with higher opportunity cost of time are the more likely employers. This finding is in line with the theory of human capital (Becker, 1985) predicting that the level of education is inversely related to the time allotted to household chores. At the current educational trend, the average number of years of education is steadily increasing. Thus, the demand for care is expected to increase forcing the government to come up with solutions, one 
of them could be a complete reorganization of the domestic work industry, especially if the government is not able to provide the adequate level of institutional care.

It is also possible to make inference about the future demand for FDWs in Lebanon which will be mostly driven by three channels: demographic changes, changes in living standards and changes in dwelling configuration. First, the past decades witnessed the completion of the demographic transition in Lebanon. According to official statistics, the average household size has decreased from 5.4 persons in 1970 and 4.8 persons in 1997, to 4.23 in 2007. Given our results related to household size and dependents, this trend is expected to put downward pressure on the demand for domestic workers. Second, we observe an improvement in living standards in the country. For example, the average growth in real gross domestic product per capita between 1999 and 2009 was around 5\%. These changes, as per our results related to consumption and wealth, are expected to increase the demand for FDWs. Third, the configuration of new housing units changed during the recent real-estate boom (2006-2010). This shift has forced property developers to move towards building units with more rooms of smaller size. In light of our results, we can also expect that these changes in dwelling characteristics to increase the future demand for FDWs.

Although, we find that female headed households are more likely to host a foreign domestic worker, our dataset does not provide enough information to conclude that this effect has a positive impact on female labor supply. As more data becomes available, it would be of interest for future research to link female labor force participation to the availability of FDWs in Lebanon. Moreover, it would become possible to control for household unobserved characteristics such as preferences for leisure by estimating a panel data model. 


\section{References}

Baxter, J., Hewitt, B. and Western, M. (2009), Who uses paid domestic labor in Australia? Choice and constraint in hiring household help, Feminist Economics, Vol. 15, No. 1, pp. 1-26.

Becker G. S. (1985), Human capital, effort, and the sexual division of labor, Journal of Labor Economics, Vol. 3, No. 1, pp. 33-58.

Bengtson, V. L. and Kuypers, J. A. (1971), Generational difference and the development stake. Aging and Human Development, Vol. 2, No. 1, pp. 249-60.

Blackett, A. (2011), Introduction: regulating decent work for domestic workers, Canadian Journal of Women and the Law, Vol. 23, No. 1, pp. 1-46.

Chan, A. (2006), The effects of full-time domestic workers on married women's economic activity status in Hong Kong, 1981-2001, International Sociology, Vol. 21, No. 1, pp. 133-59.

Cortés. P. and Pan, J. (2013), Outsourcing household production: foreign domestic workers and native labor supply in Hong Kong, Journal of Labor Economics, (Forthcoming).

Cortés, P. and Tessada, J. (2011), Low-skilled immigration and the labor supply of highly skilled women, American Economic Journal: Applied Economics, Vol. 3, No. 3, 88-123.

de Looper, M. and Lafortune, G. (2009), Measuring Disparities in Health Status and in Access and Use of Health Care in OECD Countries, OECD Health Working Papers, No. 43, OECD Publishing.

Esim, S. and Kerbage, C. (2011), The situation of migrant domestic workers in Arab states, Draft paper presented at the interregional workshop on strengthening dialogue to make migration work for development in the ESCAP and ESCWA regions, Lebanon.

Farré, L., Gonzalez, L. and Ortega, F. (2011), Immigration, family responsibilities and the labor supply of skilled native women, The B.E. Journal of Economic Analysis \& Policy, 11 (Contributions), Article 34.

Flipo, A., Fougere, D. and Olier, L. (2007), Is the household demand for in-home services sensitive to tax reductions? The French case, Journal of Public Economics, Vol. 91, No. 1-2, pp. 365-85.

Khan, F. C. (2012), Household work, labor time and the schooling of girls in rural South Asia, Journal of Developing Areas, Vol. 46, No. 2, pp. 249-67.

Hamill, K. (2011), Trafficking of migrant domestic workers in Lebanon a legal analysis, Kafa Institute, Lebanon. 
Hammarström, G. (2005), The construct of intergenerational solidarity in a lineage perspective: a discussion on underlying theoretical assumptions, Journal of Aging Studies, Vol. 19, No. 1, pp. 33-51.

International Labour Organization (ILO) (2013), Domestic Workers Across the World: Global and regional statistics and the extent of legal protection, International Labour Organization, Geneva, Switzerland.

Ireland, P. R. (2011), Female migrant domestic workers in Southern Europe and the Levant, towards an expanded Mediterranean model?, Mediterranean Politics, Vol. 16, No. 3, pp. 343-63.

Kimmel, J. and Connelly, R. (2007), Mothers' time choices: Caregiving, leisure, home production, and paid work, Journal of Human Resources, Vol. 42, No. 3, pp. 643-68.

Pollak, R. A. and Wachter, M. L. (1975), The relevance of the household production function and its implications for the allocation of time, Journal of Political Economy, Vol. 83, No. 2, pp. $255-77$.

Shah N., Badr, H. and Shah, M. (2012), Foreign live-in domestic workers as caretakers of older Kuwaiti men and women: socio-demographic and health correlates, Ageing and Society, Vol. 32, No. 6, pp. 1008-29.

Stancanelli, E. and Stratton, L. (2010), Her time, his time, or the maid's time: An analysis of the demand for domestic work, Institute for the study of labor (IZA), Discussion Paper 5253, Germany.

Suen, W. (1993), Market-procured housework: The demand for domestic servants and female labor supply, Labour Economics, Vol. 1, No. 3-4, 289-302. 


\section{Endnotes}

${ }^{1}$ According to the International Labour Organization (ILO), a domestic worker is "a wage-earner working in a [private] household, under whatever method and period of remuneration, who may be employed by one or by several employers who receive no pecuniary gain from this work". This definition was first introduced by the ILO in 1951. However, in this paper we are examining the demand for foreign domestic workers since most of the domestic work is provided by foreigners.

${ }^{2}$ See for example de Looper and Lafortune, 2009, for a discussion about government health care services in OECD countries and how they differ from developing countries.

${ }^{3}$ These wages are still considered low even after taking into account the implicit cost of housing for workers living with their employers.

${ }^{4}$ In Lebanon, a bargaining process between the household and the agency supplying the foreign worker's services determines the wage paid to the FDW. The presence of a competitive market structure on the supply side weakens the bargaining position of the agency and hence limits the wage rate.

${ }^{5}$ These figures exclude part-time non-contractual foreign domestic work as well as unpaid work.

${ }^{6}$ Authors calculations based on the report by Hamill (2011).

${ }^{7}$ Notice that this survey does not include information on part-time non-contractual foreign domestic workers.

${ }^{8}$ For robustness check, we run the full model excluding the variable wealth. Although, overall the explanatory power of the full model is slightly reduced (reduction in Ln-Likelihood ratio), the results all remain qualitatively unchanged in both size and significance. The results are available upon request.

${ }^{9}$ In Lebanon, female headed household come into being when the husband is deceased or in divorce cases.

${ }^{10}$ The variable number of rooms is exogenous in the model. In fact, this variable does not depend on the household's decision to hire or not to hire a domestic worker. In other words, the causality between number of rooms and the hiring decision is not reciprocal. Typically in Lebanon the dwelling configuration is fixed, residences are rarely remodeled to increase or decrease the number of rooms. 